\title{
ASPEK REPRODUKSI IKAN BLODOK (B. boddarti) DI PERAIRAN KABUPATEN MERAUKE
}

\author{
Sunarni* \\ *Staf Pengajar Jurusan MSP, UNMS-Merauke, Email: sunarni.ardi@yahoo.com
}

\begin{abstract}
ABSTRAK
Penurunan populasi diakibatkan oleh aktivitas manusia maupun yang diakibatkan oleh perubahan kualitas lingkungan perairan, sehingga dapat mengakibatkan keseimbangan ekologis terganggu dan kemampuan pertumbuhan serta reproduksi ikan Blodok (Boleophthalmus boddarti) menjadi terhambat. Sebagai penelitian pendahuluan penelitian ini bertujuan memperoleh informasi tentang aspek reproduksi ikan Blodok (Boleophthalmus boddarti) meliputi nisbah kelamin, ukuran pertama kali matang gonad dan tingkat kematangan gonad. Berdasarkan uji chi-square pada tiga Stasiun nisbah kelamin antara ikan jantan dan ikan betina yang tertangkap selama penelitian adalah sama, yakni 1:1 yang berarti bahwa jumlah ikan jantan dan ikan betina tidak berbeda nyata. Pada Stasiun II ukuran pertama kali matang gonad paling kecil dibandingkan dengan stasiun I dan III, yakni pada ikan Blodok jantan memiliki ukuran pertama kali matang gonad pada ukuran panjang total 123,29 mm dan pada ikan betina pada ukuran 115,83 mm. Persentase terbesar terhadap pengamatan tingkat kematangan gonad pada ikan betina diperoleh bahwa puncak pemijahan ikan Blodok betina terjadi pada bulan Maret.
\end{abstract}

Kata Kunci : Ikan Blodok, Aspek Reproduksi.

\section{PENDAHULUAN}

1.1. Latar Belakang

Setiap mahluk hidup mengalami reproduksi atau perkembangbiakan dalam siklus hidupnya, begitu juga dengan ikan memiliki kebiasaan, cara hidup dan cara makan yang berbeda. Untuk mempertahankan populasinya di alam ikan melakukan reproduksi. Ikan Blodok merupakan salah satu jenis ikan yang sangat penting untuk dikaji aspek biologi reproduksi, dikarenakan populasi ikan ini sudah mulai berkurang khususnya yang ada di Kabupaten Merauke.

Penurunan populasi diakibatkan oleh aktivitas manusia maupun yang diakibatkan oleh perubahan kualitas lingkungan perairan, sehingga dapat mengakibatkan keseimbangan ekologis terganggu dan kemampuan pertumbuhan serta reproduksi ikan Blodok (Boleophthalmus boddarti) menjadi terhambat.

Secara umum spesies ikan Blodok kurang mendapat perhatian, sehingga informasi tentang spesies ini masih sangat sedikit. Beberapa penelitian tentang spesies ini diantaranya tentang Study Lingkungan Ikan Blodok di Zona Intertidal (Bahija dkk., 2009). Study Biologi Reproduksi Ikan Blodok (Hawa, 2000). Djumanto dkk, (2012) Reproduksi Ikan Gelodok (Boleophthalmus sp.) di Pantai Brebes. Penelitian tentang aspek biologi reproduksi ikan Blodok (Boleophthalmus boddarti) di perairan Merauke belum pernah dikaji, sementara itu pemanfaatan ikan Blodok oleh masyarakat papua yang tidak terkendali berdampak pada penurunan populasi ikan tersebut, oleh karena itu penelitian tentang aspek biologi reproduksi sangat penting dilakukan guna memperoleh informasi dasar dari ikan Blodok untuk pengelolaan lebih lanjut.

1.2. Tujuan Penelitian

Penelitian ini bertujuan untuk memperoleh informasi tentang aspek 
reproduksi ikan Blodok (Boleophthalmus boddarti) meliputi nisbah kelamin, ukuran pertama kali matang gonad dan tingkat kematangan gonad. Informasi ini diharapkan dapat dijadikan sebagai dasar pengelolaan terhadap ikan Blodok.

\section{METODE PENELITIAN}

2.1. Waktu dan Lokasi Penelitian

Penelitian dilakukan pada bulan Maret hingga Mei 2013 di Perairan Kabupaten Merauke, Propinsi Papua. Pengambilan sampel dilakukan dua kali dalam satu bulan. Penelitian ini menggunakan Metode Survei, dan penetuan titik sampling dilakukan secara purposive (Gambar 1).

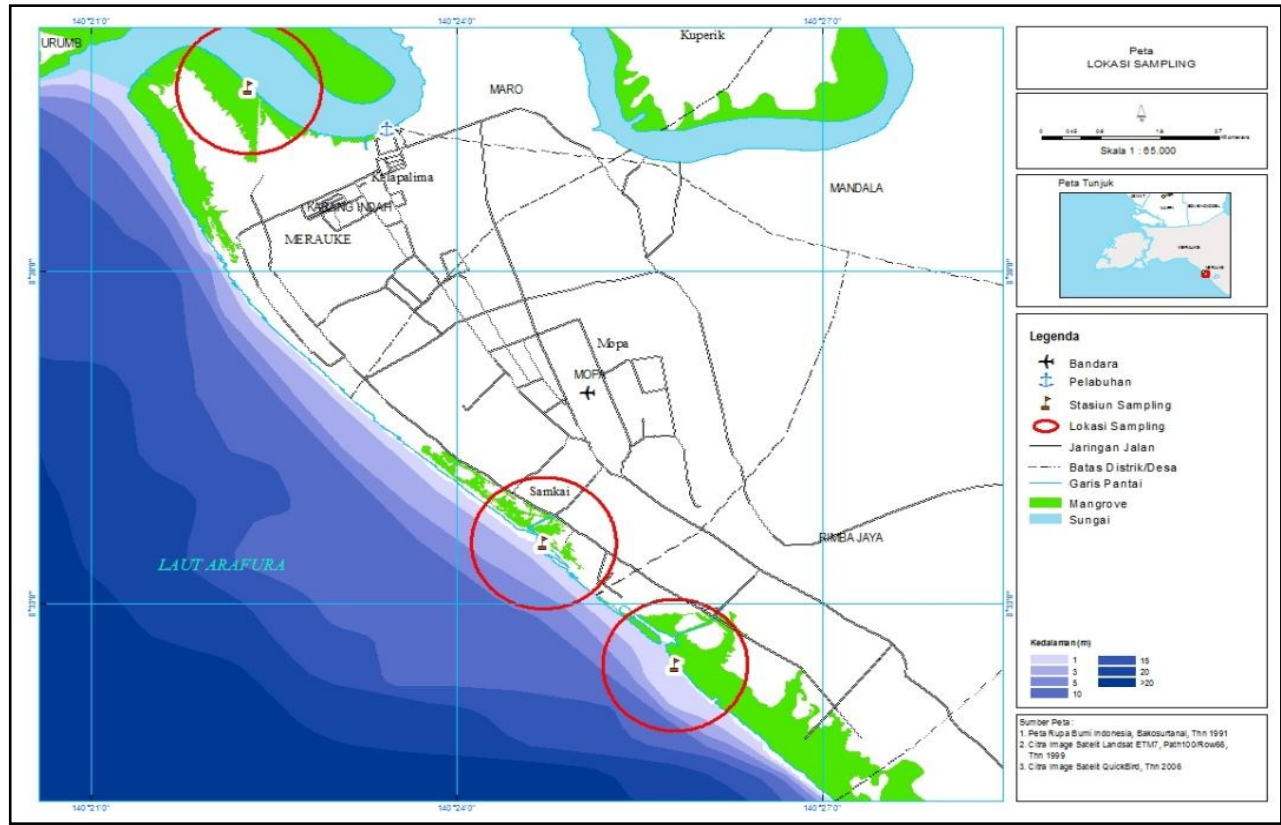

Gambar 1. Lokasi pengambilan sampel ikan Blodok (Boleophtalmus Boddarti).

\subsection{Alat dan Bahan}

Alat yang digunakan dalam penelitian yaitu: timbangan elektrik dengan ketelitian 0,1 g, digunakan untuk menimbang sampel ikan, kaliper digunakan untuk mengukur panjang tubuh ikan, kertas label, seperangkat alat bedah, wadah, kain lap dan tissue, kertas label, dan cawan petri.

Ikan Blodok diambil dari hasil tangkapan masyarakat yang dilakukan secara manual. Jumlah sampel yang digunakan dalam penelitian adalah 683 ekor, selanjutnya dilakukan pengukuran, penimbangan dan pembedahan untuk mengetahui jenis kelamin dan tingkat kematangan gonad (TKG).

\subsubsection{Analisa Data Nisbah Kelamin}

Penentuan nisbah kelamin nisbah kelamin dihitung dengan cara membandingkan jumlah ikan Blodok jantan dan betina. Nisbah kontingensi (Steel dan Torrie 1989, Sujana 1992, dalam Andi Omar, 2012). Rumus yang digunakan adalah:

$$
\begin{aligned}
& X^{2}=\sum_{i=1}^{B} \sum_{j=1}^{K} \frac{(O i j-E i j)^{2}}{E i j} \\
& \text { Eij }=\frac{(\text { nio } \times n o j)}{n}
\end{aligned}
$$

2.2.2. Analisa Data Ukuran Pertama Matang Gonad

Penentuan ukuran pertama matang gonad dilakukan sesuai dengan metode Spearmen-Karber (Udupa, 1986) sebagai berikut :

$$
\mathbf{m}=X k+\frac{X}{2}-\left\{X \sum P i\right\}
$$

jika $\propto=0,05$, maka batas-batas kepercayaan 95 $\%$ dari $\mathrm{m}$ adalah :

$\operatorname{antilog}=\left[m \pm 1.96 \sqrt{X^{2} \sum\left(\frac{p i-q i}{n i-1}\right)}\right]$

\subsubsection{Analisa Data Tingkat Kematangan Gonad (TKG)}

Pengamatan TKG dilakukan secara morfologi. Dasar yang dipakai untuk menentukan TKG secara morfologi adalah bentuk, ukuran panjang, warna dan perkembangan isi gonad. kriteria TKG ikan jantan dan ikan betina yang digunakan 
mengikuti petunjuk Cassie modifikasi Effendie

dilihat pada Tabel 1.

(1984). Kriteria masing-masing tingkatan dapat

Tabel 1. Tingkat kematangan Gonad Ikan Belanak di Perairan Sungai Cimanuk, Indramayu modifikasi Effendie (1984).

\begin{tabular}{|c|c|c|}
\hline TKG & Betina & Jantan \\
\hline I & $\begin{array}{l}\text { Ovari seperti benang, panjang } \\
\text { sampai ke depan rongga tubuh, } \\
\text { warna jernih, permukaan licin. }\end{array}$ & $\begin{array}{l}\text { Testis seperti benang, lebih pendek } \\
\text { (terbatas) dan terlihat ujungnya di rongga } \\
\text { tubuh, warna jernih. }\end{array}$ \\
\hline II & $\begin{array}{l}\text { Ukuran ovari lebih besar, } \\
\text { pewarnaan lebih gelap kekuning- } \\
\text { kuningan, telur belum terlihat jelas } \\
\text { dengan mata. }\end{array}$ & $\begin{array}{l}\text { Ukuran testis lebih besar, pewarnaan } \\
\text { putih seperti susu, bentuk lebih jelas dari } \\
\text { tingkat I. }\end{array}$ \\
\hline III & $\begin{array}{l}\text { Ovari berwarna kuning, secara } \\
\text { morfologi telur mulai kelihatan } \\
\text { butirnya dengan mata. }\end{array}$ & $\begin{array}{l}\text { Permukaan testis tampak bergerigi, } \\
\text { warna makin putih, testis makin besar, } \\
\text { dalam keadaan diawet mudah putus. }\end{array}$ \\
\hline IV & $\begin{array}{l}\text { Ovari makin besar, telur berwarna } \\
\text { kuning, mudah dipisahkan, butir } \\
\text { minyak tidak Nampak, mengisi } \\
\text { setengah sampai dua pertiga rongga } \\
\text { perut, usus terdesak. }\end{array}$ & $\begin{array}{l}\text { Seperti pada tingkat II, tampak semakin } \\
\text { jelas, testis semakin pejal. }\end{array}$ \\
\hline V & $\begin{array}{l}\text { Ovari berkerut, dinding tebal, butir } \\
\text { telur sisa terdapat dekat pelepasan, } \\
\text { banyak telur sisa berisi seperti pada } \\
\text { tingkat II. }\end{array}$ & $\begin{array}{l}\text { Testis di bagian belakang kempis dan } \\
\text { dibagian dekat pelepasan makin berisi. }\end{array}$ \\
\hline
\end{tabular}

\section{HASIL DAN PEMBAHASAN}

\subsection{Nisbah Kelamin}

Jumlah ikan yang tertangkap pada Stasiun I sebanyak 94 ekor yang terdiri dari 54 jantan dan 40 betina. Berdasarkan uji chisquare peroleh nilai chi-square tabel: $X^{2} 0.05=$ 5,99 dan $X^{2} 0.01=9,21$, sedangkan nilai $X^{2}{ }^{2}$ hitung $=$ 1,1070. karena $X^{2}$ hitung $<X^{2}$ tabel, maka jumlah ikan jantan dan ikan betina tidak berbeda nyata pada setiap bulannya. Dengan demikian nisbah kelamin antara ikan jantan dan ikan betina yang tertangkap adalah adalah $1: 1$ atau seimbang.

Ikan Blodok yang tertangkap selama pengamatan pada Stasiun II berjumlah 233 ekor yang terdiri dari 128 jantan dan 105 ikan betina. Setelah dilakukan uji chi-square, maka diperoleh nilai chi-square tabel: $X^{2} 0.05=5,99$ dan $X^{2} 0.01=9,21$, sedangkan nilai $X^{2}$ hitung $=0,4081$ karena $X^{2}$ hitung $<X^{2}$ tabel, hal ini berarti jumlah antara ikan jantan dan ikan betina yang tertangkap di Kelurahan Samkai tidak berbeda nyata pada setiap bulannya.

Jumlah ikan Blodok yang tertangkap pada Stasiun III selama penelitian berjumlah berjumlah 210 ekor yang terdiri dari 99 jantan dan 111 betina. Berdasarkan uji chi-square (Lampiran 9), diperoleh nilai chi-square tabel:
$X^{2} 0.05=5,99$ dan $X^{2} 0.01=9,21$, sedangkan nilai $X^{2}{ }_{\text {hitung }}=0,7201$. karena $X^{2}$ hitung $<X^{2}$ tabel, maka jumlah ikan jantan dan ikan betina yang tertangkap tidak berbeda nyata pada setiap bulannya. Dengan demikian nisbah kelamin antara ikan jantan dan ikan betina yang tertangkap adalah 1:1 atau seimbang.

Berdasarkan jumlah sampel yang diperoleh selama penelitian maka Stasiun II memiliki jumlah sampel paling banyak yakni 233 ekor, selanjutnya pada Stasiun III berjumlah 210 ekor dan jumlah sampel yang paling sedikit terdapat pada Stasiun I yakni berjumlah 94 ekor. Sedangkan berdasarkan uji chi-square pada tiga Stasiun nisbah kelamin antara ikan jantan dan ikan betina yang tertangkap selama penelitian adalah sama, yakni 1:1 yang berarti bahwa jumlah ikan jantan dan ikan betina tidak berbeda nyata.

\subsection{Ukuran pertama kali matang gonad}

Berdasarkan hasil perhitungan dengan menggunakan Metode Spearman Karber (Udupa 1986) pada Stasiun I, diperoleh kisaran pertama kali matang gonad pada ukuran 144 mm dan pada ikan betina pada ukuran 120,26 mm. Pada Stasiun II ukuran pertama kali matang gonad pada ikan Blodok jantan 
memiliki ukuran pertama kali matang gonad pada ukuran panjang total $123,29 \mathrm{~mm}$ dan pada ikan betina pada ukuran $115,83 \mathrm{~mm}$. Sedangkan pada Stasiun III ukuran pertama kali matang gonad pada ikan Blodok jantan berukuran $136,71 \mathrm{~mm}$ dan ikan betina memiliki ukuran pertama kali matang gonad yakni pada ukuran $143,37 \mathrm{~mm}$.

Dengan demikian maka ikan Blodok yang ada di Stasiun II Kelurahan Samkai lebih cepat matang gonad dibandingkan dengan ikan Blodok yang ada di Stasiun I Kelurahan Karang Indah dan Stasiun III Rimba Jaya. Hal ini dikarenakan banyaknya kegiatan penangkapan ikan dilokasi tersebut serta kondisi lingkungan yang kurang mendukung bagi pertumbuhan yakni rendahnya kandungan Bahan Organik Total (BOT) 25,65\%, hal ini sangat berbeda dengan kondisi lingkungan yang ada di Stasiun I Kelurahan Karang Indah. Dengan lebih cepat matang gonad juga merupakan salah satu strategi untuk mempertahankan keberadaan dari spesies ikan Blodok dari kepunahan.

\subsection{Tingkat Kematangan Gonad}

Tingkat kematangan gonad ikan betina yang tertangkap pada Stasiun I menunjukkan puncak pemijahan tertinggi terjadi pada bulan Maret. Pada Stasiun II tingkat kematangan gonad ikan betina di Kelurahan Samkai diperoleh puncak pemijahan terjadi pada bulan Maret.
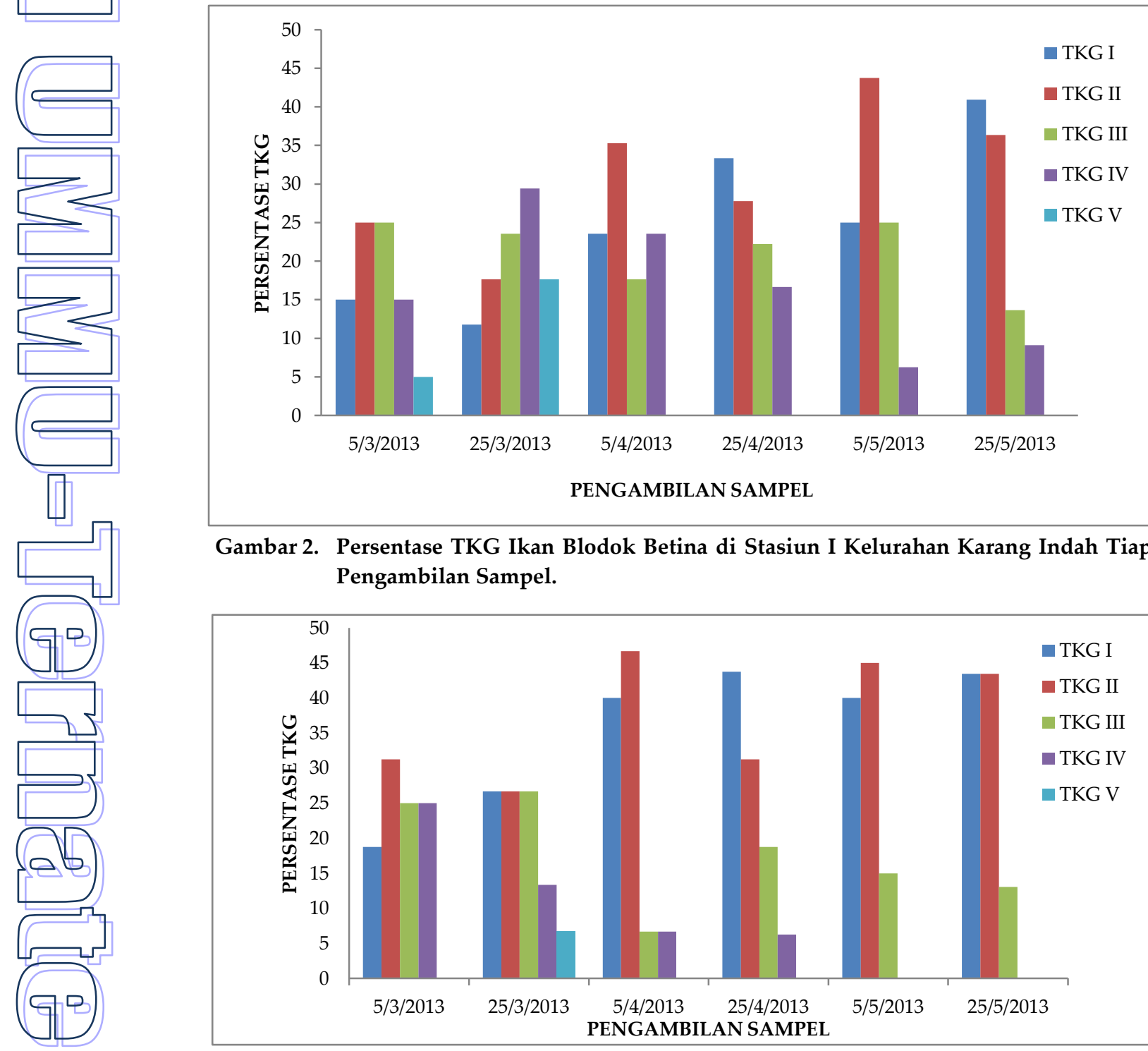

Gambar 2. Persentase TKG Ikan Blodok Betina di Stasiun I Kelurahan Karang Indah Tiap Pengambilan Sampel.

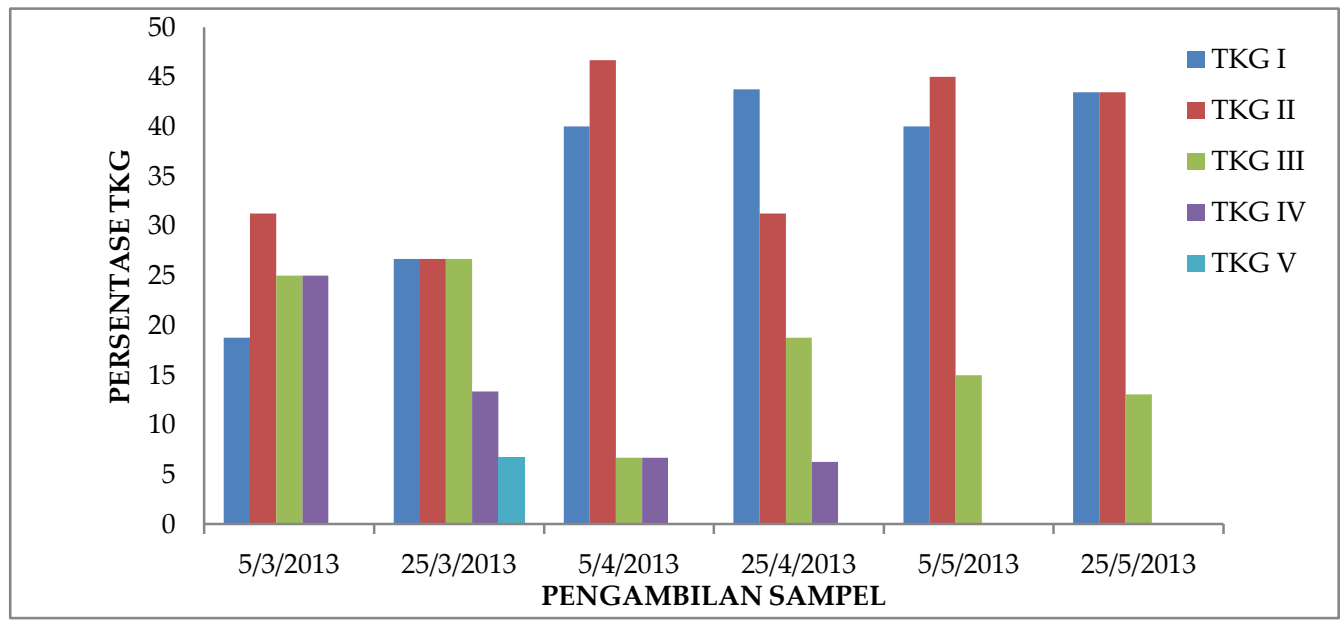

Gambar 3. Persentase TKG Ikan Blodok Betina di Stasiun II Kelurahan Samkai Tiap Pengambilan Sampel. 

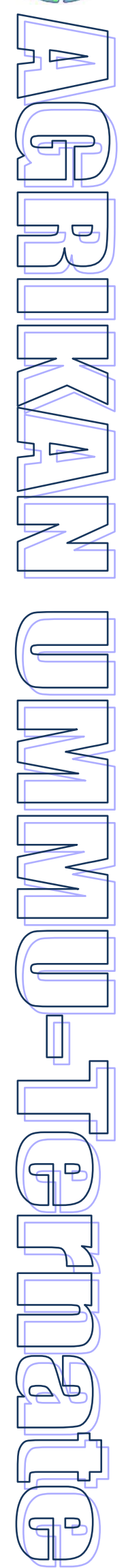

Dengan demikian tingkat kematangan gonad pada setiap pemgambilan sampel menunjukkan bahwa bulan Maret merupakan puncak pemijahan pada ikan Blodok pada tiga Stasiun penelitian yakni Stasiun I Kelurahan Karang Indah, Stasiun II Samkai dan Stasiun III Rimba Jaya.

\section{PENUTUP}

Perbandingan nisbah kelamin ikan Blodok jantan dan betina di tiga lokasi penelitian adalah satu banding satu ( $1: 1)$, berarti jumlah ikan jantan yang tertangkap relatif hampir sama banyaknya dengan jumlah ikan betina yang tertangkap. Ukuran pertama kali matang gonad ikan Blodok di Stasiun II memiliki ukuran panjang total paling kecil dibandingkan dengan ikan Blodok yang ada di Stasiun I dan III. Persentase terbesar terhadap pengamatan tingkat kematangan gonad pada ikan betina diperoleh bahwa puncak pemijahan ikan Blodok betina terjadi pada bulan Maret.

\section{DAFTAR PUSTAKA}

Bahija E. Al-Behbehani and Hussain.MA.Ebrahim. (2009). Environmental Studies On The Mudskippers In The intertidal Zone Of Kuwait Bay. Science Department, College of Basic Education, Paaet, Kuwait, http://repository.ipb.ac.id, Diakses 5 April 2012.

Djumanto, Eko Setyobudi dan Rudiansyah.(2012). Reproduksi ikan Gelodok (Boleophthalmus sp) Di Pantai Brebes. Yogyakarta. Universitas Gajah Mada.

Effendie M.I. (2002). Biologi Perikanan. Yayasan Pustaka Nusatama. Jakarta.

Effendie M.1. (1997). Biologi Perikanan. Yayasan Pustaka Nusatama. Jakarta.

Hawa.S. (2000). Study Biologi Reproduksi Ikan Blodok (Boleophthalmus bod darti) Diperairan Ujung Pangkah. Jawa Timur. tidak diterbitkan. Institute Pertanian Bogor.

Omar.A.S.Bin. (2004). Model Praktikum Biologi Perikanan. Jurusan Perikanan Fakultas Ilmu Kelautan dan Perikanan. Universitas Hasanuddin Makassar.

Prastyo B. (2006). Studi Biologi Reproduksi Ikan Tembang (sardinella fimbriata) di Perairan Ujung Pangkah, Kabupaten Gresik Jawa Timur Departemen Manajemen Sumberdaya Perairan, Fakultas Perikanan dan Ilmu Kelautan, Institut Pertanian Bogor

Ricker W.E.(1975). Compulation and Interiretation of Biological Statistic of Fish Populations. Departement of the Environment Fisheries and Marine Services. Ottawa. 382. 